\title{
Brazilian Studies Then and Now
}

Anthony Pereira. ${ }^{1}$

In 1912 the Brazilian diplomat, scholar, and bibliophile Manuel de Oliveira Lima (1867-1928) gave six lectures at Stanford University that encapsulated his views of what we now call Brazilian Studies. In these lectures he advanced arguments about what made Brazil distinctive and interesting; how the country's history, culture, and contemporary society should be understood; which stereotypes about it were not particularly accurate or helpful; and what exciting new developments would shape the country in the future. The lectures make fascinating reading today, not only because they show the contours of one person's vision of Brazilian Studies at the beginning of the last century, but because they reveal differences and similarities between Oliveira Lima's intellectual horizon and the one we face today.

The first part of this essay will summarize Oliveira Lima's lectures. In the following section, I will point out some of the discrepancies between Oliveira Lima's worldview and scholarly debates in the twenty-first century. These include the Eurocentrism of his frame of reference; the unproblematic nature of the nation-state in his thinking; and his largely negative view of Brazil's racial heritage. All of these positions, I argue, have been significantly rethought since Oliveira Lima's day, and must continue to be rethought if Brazilian Studies are to flourish now. In the third part of the essay, I will point out that, on the other hand, many of Oliveira Lima's problems are still our own. These include the perennial problem of establishing an adequate context for the study of Brazil. The difficulty of justifying an academic discipline that revolves

\footnotetext{
${ }^{1}$ Anthony W. Pereira is a Professor and Director of the Brazil Institute at King's College London. His most recent book is Ditadura e Repressao (Sao Paulo: Paz e Terra, 2010). He will serve as Vice-President of the Brazilian Studies Association (BRASA) from 2012 to 2014.
}

Brasiliana - Journal for Brazilian Studies. Vol. 1, n.1 (Sept. 2012). ISSN 2245-4373. 
around the study of a single country is a related problem. In addition, there is the challenge of how to unite disparate and specialized disciplines in order to appreciate Brazil's complexity and trajectory in the modern world. Each of these issues will be discussed in turn. In the fourth and final section, I will make some claims about what sorts of questions and issues scholars in Brazilian Studies should be delving into, in order to maintain the field as a vibrant and creative one in the $21^{\text {st }}$ century.

\section{Six Lectures}

Manuel Oliveira Lima was invited to speak by the History Department at Stanford, a university that had been founded in 1891. He gave his lectures in the autumn of 1912. The lectures were first published in 1914 under the title The Evolution of Brazil compared with that of Spanish and Anglo-Saxon America. The purpose of the presentations, according to Oliveira Lima, was to describe "the mind of...Latin American society" to his audience, as well as "the literary shape taken by the traditional expression of its intellectuality..."(Oliveira Lima, 1966:90). In his talks, Oliveira Lima ranged over history, especially the struggle for independence in Latin America, political theory, and literature. The title suggests the comparative context within which Oliveira Lima worked. He was primarily interested in comparing and understanding the relationship between Brazil and Spanish or Hispanic America. But other countries were important too: the United States ("Anglo-Saxon America”); Great Britain; France; Spain; Germany; and Portugal.

For Oliveira Lima, Brazil was following a path, more or less autonomously, towards a higher form of "civilization" already carved out by the European powers and the United States. Influenced by the evolutionism of Herbert Spencer, Oliveira Lima believed that there was a clear hierarchy of people and nations, and Brazil was making 
upward progress within it. The lectures make the case for Brazil's membership in and contributions to this family of nations, or civilization.

It was important for Oliveira Lima to point out Brazil's uniqueness in Latin America. Four factors that contributed to Brazil's distinctiveness in Latin America, according to Oliveira Lima, were its Portuguese heritage, its monarchy, its territorial unity, and its relatively low degree of municipal autonomy. The country's colonization by Portugal, a more unified country than Spain, created an "organic particularism" in Brazil (Oliveira Lima 1966: 56). Portugal's prohibition on printing presses and universities in its Brazilian colony, which contrasts with Spain's permission of both of these in Spanish America, meant that many upper-class Brazilians studied in Coimbra in the $18^{\text {th }}$ and $19^{\text {th }}$ centuries and contributed to the intellectual life and the affairs of the court in Portugal to a far greater extent than their Spanish American counterparts did in Spain.

For Oliveira Lima, the monarchy had made Brazil a model of order and progress in Latin America in the $19^{\text {th }}$ century, preserving the country's territorial integrity and allowing for territorial expansion in the late $19^{\text {th }}$ and early $20^{\text {th }}$ century. In addition, for Oliveira Lima the monarchy had exercised a moderating, liberal influence on the nation's political trajectory, holding at bay the more despotic tendencies of the oligarchies that surrounded the crown "at a time when a condition of anarchy prevailed in nearly all the rest" of Latin America (Oliveira Lima 1966: 117). Oliveira Lima's admiration of the monarchy made him skeptical of both democracy and republicanism. For him, "Brazil under the Imperial régime enjoyed all political rights and privileges to such a degree that from this point of view, after the establishment of the Republic, there remained nothing for it to gain, but only to imitate" (Oliveira Lima 1966: 125). Oliveira Lima claimed that the monarchical ideal had been cherished by many of Latin America's best minds, making Great Britain rather than the United States a favoured role model, 
and that in the $19^{\text {th }}$ century, monarchy was "truly suited to the social status of Latin America" (Oliveira Lima 1966: 117). If monarchy had been adopted in Spanish America, he argued, the region might have been able to avoid the fragmentation and warfare that marked the first decades of its independent political life.

Oliveira Lima was keen to defend Brazil and Latin America to his audience at Stanford. He argued that "the culture of the Latin American colonies at that time [the colonial period] was superior, in certain respects, to that of the Anglo-American colonies, whose development today astonishes the world" (Oliveira Lima 1966: 38). He claimed that "charity and education "reached the Latin section of the New World earlier than it did the Anglo-Saxon section" (Oliveira Lima 1966: 41). In addition, he declared that Latin American independence was produced by the same ideas that inspired North American de-colonization; the two regions of the Americas were united in this respect.

Oliveira Lima was also keen to dispel stereotypes about Brazil and Latin America. He lamented that Latin America has "frequently been treated with excessive severity, and at times cruelly ridiculed and even maliciously slandered" (Oliveira Lima 1966: 127). Latin America was not full of political and social unrest; its people were not unusually indolent or ignorant (Oliveira Lima 1966: 114; 127); and it was undergoing economic, political, and social progress, or "moralization by labour and education" (Oliveira Lima 1966: 93). "Violence", he said, "is yielding daily the first place to culture, or rather culture, which at no time was unknown among the Iberian societies of the New World, is gradually recovering the position which belongs to it" (Oliveira Lima 1966: 126).

Where Oliveira Lima saw a key difference between Brazil and Spanish America, on one hand, and "Anglo-Saxon" America, on the other, was in the realm of political institutions. In the United States, political institutions fit the character of the people. Federalism was real, and not a façade for centralized rule. In Latin America, on the other 
hand, state institutions were hobbled by "administrative incapacity" which he ultimately attributed to the people's lack of political education (Oliveira Lima 1966: 5051). Latin America was also behind in the development of the rule of law. "It is frequently impossible to distinguish with certainty the laws that are applied from those which were not applied, or which were not applied as they ought to have been, and it is not without difficulty that we are enabled to define with precision the duties of the several authorities", he wrote. Consequently, the "Ibero-Latin people...were in need of one law - one which should put into execution all the existing ones" (Oliveira Lima 1966: 58).

Looking toward the future, Oliveira Lima was optimistic. Brazil's (and Latin America's) progress would continue, and its achievements in science, law, and literature were already being recognized internationally. With regard to science, Oliveira Lima highlighted the work of the Oswaldo Cruz laboratory in Rio de Janeiro. In the legal field, he mentioned Rui Barbosa's defense of multilateralism at the Hague Convention of 1907 (for a discussion of this, see Cardim 2008). In literature, he discussed several authors, including José Verissimo and José de Alencar (Oliveira Lima 1966: 94-111). Furthermore, for Oliveira Lima, the Pan-American movement was leading to the consolidation of Latin America as a region, as Brazil increasingly converged with its Spanish American neighbours².

In summary, Oliveira Lima's worldview combined a number of different elements. Spencerian evolutionism gave his portrait of Brazil and Latin America a conservative and hierarchical hue, although one tinged by a Victorian belief in economic, political, and social progress. He was a monarchist and argued that Brazil was politically distinctive and superior in Latin America, at least in the $19^{\text {th }}$ century. His

\footnotetext{
${ }^{2}$ In this respect, his view of Brazil was diametrically opposed to those who refused to see the country as part of "Latin America"; see Bethell 2010.
}

Brasiliana - Journal for Brazilian Studies. Vol. 1, n.1 (Sept. 2012). ISSN 2245-4373. 
ability to range over a number of different topics and combine history, politics, current affairs and literature was impressive. But in at least three areas of his thinking he looks remarkably anachronistic today. It is to those topics that we now turn.

\section{Differences between 1912 and 2012: Eurocentrism, the Naturalized Nation-State, and Racial Pessimism}

In 1912, Oliveira Lima spoke to an audience for whom Europe was the fountainhead of its genetic stock, the foundation of its material progress, the source of its culture, and the yardstick with which it measured its most cherished achievements. "The American continent, in the southern hemisphere and in its eastern coast, advances, so to speak, in search of the civilization of the Old World", he declared (Oliveira Lima 1966: 37). He added: "For we must never forget that the history of Latin America is nothing more than that of the Iberian Peninsula transplanted to a new scene in which new human elements take part, and one must seek in the environment and traditions of Europe for the thread of its institutions and ideals" (Oliveira Lima 1966: 52). If the past had been heavily influenced by Europe, so would be the future. Oliveira Lima believed that "America is and will continue to be more and more the field for the employment of European capital, of study for European scholars, of commerce for European merchants, of activity for European immigrants. Only thus will the New World fulfill its historical and social mission and redeem the debt contracted with Europe, which has given it its civilization" (Oliveira Lima 1966: 129).

Oliveira Lima also spoke highly of the United States. He congratulated his American audience on "the present superiority of your civilization" (Oliveira Lima 1966: 40). He attributed this superiority to the close ties between the United States and Europe. "The Anglo-Saxon population which was transplanted to North America and 
there propagated itself" he asserted, "was and continues to be fundamentally the same people as that of the mother country, and consequently their institutions are the same and fit to them" (Oliveira Lima 1966: 121).

These declarations strike the modern reader as excessively and obsessively Eurocentric. Oliveira Lima made them before the carnage of World War I, which did so much damage to Europe's claim to be the apogee of civilization, and contributed to the rise to global hegemony of the USA, consolidated after World War II. In more recent years, Europe's relative decline has continued, not in relation to the United States, but with regard to rising powers in the global South, especially Asia. So while its relationships with Latin America, Europe and the United States are still important to Brazil, this frame of reference is no longer an adequate basis for Brazilian Studies. The constrictive triangle formed by an exclusive focus on these three regions must be transcended. The world is experiencing globalization, defined as "the expansion and intensification of social relations and consciousness across world-time and world-space" (Steger 2009: 15). This process has multiplied Brazil's connections to the rest of the world; other actors are waking up to the importance and distinctiveness of Brazil, while Brazilians are opening up to new transnational opportunities as never before. Brazil is a global trader, and its most important commercial partnership is now with China rather than the United States. Its model of development is seen as a potential inspiration to Sub-Saharan Africa. Its diplomacy has an impact in the Middle East. It is a member of the BRICS group of countries (Brazil, Russia, India, China, and South Africa), a category invented by an economist at an investment bank and now an actor in world affairs ${ }^{3}$.

Given these developments, Brazil can no longer be seen as part of a simple dichotomy between the Old and New World, America and Europe. Scholars in Brazilian

\footnotetext{
${ }^{3}$ For a book by the person commonly credited with the invention of the BRICs acronym, see O'Neill 2011. The political grouping is BRICS rather than BRICs, because South Africa has been added.
} 
Studies must acknowledge these developments, and expand their comparative and transnational frameworks accordingly.

Of course, it is not new to go beyond Europe and the United States in the study of Brazil. Charles Boxer, for example, placed Brazil in global perspective in the 1960s. In Boxer's case, this was a study that saw Brazil as part of Portugal's "seaborne Empire", an empire developed through centuries of oceanic voyages from Portugal across the Atlantic to Brazil, round the Cape of Good Hope to India, and on to other parts of Asia (Boxer 1973). The challenge today is to update this global vision in order to comprehend the complexity of Brazil's role in contemporary world affairs. Only a global perspective can give due recognition to Brazil's participation in myriad, complex transnational networks.

A second topic raised by Oliveira Lima in his 1912 lectures was the subject of nationalism and the nation-state. Oliveira Lima recognized that national consciousness in Latin America was a relatively recent phenomenon. Before the last quarter of the nineteenth century, regional identities, cemented by loyalties to local landowners and caciques, were more common forms of identity than nationality in most Latin American countries. Oliveira Lima died before the state's widespread use of new communication technology, especially radio, to propagate national identity. (This was joined with slightly older policies such as the creation of national curricula in public school systems and mass recruitment into the military.) Interestingly, Oliveira Lima looked forward to the supersession of national identity in Latin America by an incipient Pan-American (not just Latin American) consciousness.

As with his Eurocentrism, Oliveira Lima's view of the nation-state seems antiquated from the vantage point of the twenty-first century. He assumed, correctly, that the development of capitalism, state formation and communications technology would cement national identity, and he hoped (perhaps in a utopian fashion) for the 
development of a Pan-American consciousness and identity, one in which the United States would be an ally of, but not dominant over, the rest of Latin America. Developments since 1912 have altered our understandings of the nation-state and nationalism, however. Waves of scholarship have "deconstructed" nationalism, pointing to the arbitrariness and contingency of its social construction (Anderson 1987, Hobsbawm, 1991). In the words of John Gray, "nationality is a work in progress rather than a settled condition bequeathed by history"(Gray 2012). At the same time, globalization seems to be weakening national identity.

These developments make nationalism and the nation-state problematic entities for scholars. However, in my judgment, they do not invalidate Brazilian Studies. Benedict Anderson famously called nations "imagined communities", but if hundreds of millions of people share this imagined space, the resulting construct is meaningful in important ways. Perhaps the most helpful insight of the literature on nationalism is that Brazilian Studies, like other scholarly endeavours, can be manipulated by states, and shaped by projections of state power. (Corporations and diasporic communities can also strongly influence area studies.) This kind of capture is something that scholars should seek to avoid - by allowing a multiplicity of voices into the field, by being self-reflective and open about the sources of their own biases, and by being careful, and critical, of claims about national "character", national uniqueness, national superiority, and the like. We need to open up Brazilian Studies to views from China, Singapore, India, Japan, South Africa, and continental Europe - where research on Brazil is being conducted and add these to the perspectives that are already familiar to us, from places such as Brazil, the United States, and the United Kingdom.

Perhaps the most objectionable element in Oliveira Lima's thinking is his view of race. Like many other intellectuals, he harbored prejudices about people and races that were conventional in his era. He believed that people of aristocratic lineage were 
superior to commoners, and that Afro-Brazilians and indigenous people were inferior to whites. He celebrated the European conquest of the Americas because he saw the indigenous societies as "barbarous...semi-civilizations" and Spanish and Portuguese society as representing a higher plane of human progress (Oliveira Lima 1966: 17). Like North American scholars of the same era, he associated whiteness with progress, and blackness with backwardness. For example, he remarks, "as a whole the legacy from the negro race was unfortunate. The legacy consists (...) of defects of language, vices of blood, wrong conceptions of life and death, gross superstitions, fetishism, and a total lack of comprehension of every lofty sentiment of honour and human dignity" (Oliviera Lima 1966: 38-39).

However, Oliveira Lima also believed that Brazil was advantaged, in some respects, vis-à-vis the United States because it had tolerated a greater degree of race mixture in its society. Although he subscribed to pseudo-scientific ideas of racial superiority he was not, strictly speaking, a racial pessimist. He was a racial "optimist", in that he believed that Brazil would be "whitened" to such an extent that "mulattos" would cease to exist and Brazil would become "a nursery of the white race and a centre of Latin civilization" (Oliviera Lima 1966: 29). The United States, in contrast, had a far more serious racial problem. In an arresting passage, he writes:

"Yet we of Latin America have already settled this same [race] problem in the most satisfactory manner by fusion, a fusion in which the inferior elements will shortly disappear. Thus, when mulattoes and half castes shall no longer exist among us, when the Negro or Indian blood shall have become diluted in European blood, which in times past and not far distant - it must not be forgotten - received its contingents of Berbers, Numidians, Tartars, and other races, you [the United States] will be 
threatened with preserving indefinitely within your confines irreducible populations, of diverse colour and hostile sentiments" (Oliveira Lima 1966: 40).

Such comparisons were common in the early $20^{\text {th }}$ century. One scholar has argued that the comparison of race in Brazil and the United States "constitutes one of the richest veins of comparative history available" (Seigel 2005: 67). The same scholar has pointed out the contradiction inherent in the view expressed by Oliveira Lima, in which praise of racial tolerance and mixture is undermined by a racist logic that sees whitening as the only solution for Brazil's racial "problem". But by referring to the admixture of "Berbers, Numidians, Tartars and other races" into "European blood", Oliveira Lima is at least suggesting that racial essentialism, based on the assumption of the "purity" of the "white" race, is incorrect. ${ }^{4}$ In this sense he anticipates the modern understanding of racial categories, which is that they are not supported by science, are entirely arbitrary, and thus, like national identity, "socially constructed".

Clearly, the debate about race in Brazil has moved well beyond the retrograde and narrow confines within which Oliveira Lima worked. Today, the argument concerns the best way to reduce racial inequality. On one side, advocates of US-style "affirmative action" policies argue that a race-neutral stance on the part of state institutions will merely perpetuate long-entrenched inequalities and subtle processes of racial discrimination (Johnson 2008). On the other side, critics describe affirmative action as wholly inappropriate for Brazil, because it is based on a "biracial" understanding of racial difference that undermines the republican ideal of equality of citizenship (Kamel

\footnotetext{
${ }^{4}$ Interestingly, Seigel leaves this phrase out of the quotation when she cites it in her article, presumably because she is keen to indict Oliveira Lima as a racial "essentialist" who believes in the "purity of the white race". See Seigel 2005: 70 .
} 
2007). It is unclear how this debate will be resolved. Affirmative action for AfroBrazilians and indigenous people has been put in place in many Brazilian universities, for example. But it seems likely that within Brazilian Studies, comparisons of race in the United States and Brazil will continue to be used as "tools with which to intervene in debates over the scope and content of racial categories, national identity, and state policy regarding both" (Seigel 2005: 67).

\section{Similarities Between 1912 and 2012: Comparative Contexts, the Single-Country Straightjacket, and Interdisciplinarity}

In the preceding section I argued that at least three elements in Oliveira Lima's thinking have been overtaken by events, and need to be re-examined and rethought. However, it is also the case that Oliveira Lima confronted challenges, in his thinking about Brazil, that we still face today. These are how to place Brazil in comparative and global context; how to justify an academic area that revolves around just one country; and how to combine various disciplines in order to understand Brazil.

To start with the first issue, what is Brazil a case of? If we want to understand, for example, the quality of Brazilian democracy, what should be our yardstick? Abstract political theory? Quantitative indices of democracy, such as those constructed by Freedom House or Polity IV? Qualitative case studies of long-lived and supposedly robust democracies? Evidence about the aspirations of the Brazilian people? Past experience with democracy in Brazil? Global trends in democratic practices? Anyone teaching or researching about Brazil will face these kinds of questions about the adequate conceptual and comparative basis for their enterprise. As we have seen, Oliveira Lima solved this dilemma by comparing Brazil to three sets of countries: the European colonial powers who were the architects of the "civilization" he identified 
with; Brazil's Spanish American neighbours, who shared with Brazil certain similarities in terms of geography, colonial experience and political trajectory; and the rising power and American hegemon of the early twentieth century, the United States. As I have argued above, this trilateral framework is no longer adequate for our times, but we still sometimes need to compare in order to answer many of the big questions about Brazil that we would like to ask.

Or do we? Seigel rejects the comparative method because it is based on the "hermeneutic preeminence of nations" and fails to adequately recognize nations as "fragile, constructed, imagined". She believes that transnational scholarship that "examines units that spill over and seep through national borders" is superior to international comparison. For her, "Comparison requires the observer to name two or more units whose similarities and differences she or he will then describe. This setup discourages attention to exchange between the two (...). Comparisons obscure the workings of power" (Seigel 2005: 63, 65). I believe that this view, while provocative and interesting, is wrong. One can compare and analyze exchange at the same time; it is a false dichotomy to say that only one or the other is possible. For example, in a subfield that I am familiar with, the study of state formation, good scholars analyze both the endogenous development of national states and how states interact with each other within regional and global systems (Tilly 1991).

Similarly, to rule out the possibility of comparison is to reject some of the most exciting new developments in Brazilian Studies. For example, Brazil is now being compared to other large "emerging" or "emerged" countries such as China and India. States in these "BIC" countries face many of the same dilemmas - for example, to secure adequate and "green" sources of energy; to prevent and mitigate environmental damage and to adapt to climate change; to manage supplies of fresh water and other vital natural resources; to improve public services such as health, education, and 
transportation; to reduce poverty and income inequality; to build institutions of regional governance so as to mitigate conflict; to bring down levels of violence within the national borders; and to secure an influential place in the arenas of global governance. One can compare what states in Brazil, China and India are doing in these areas, but one must also analyze exchange between them, because they are cooperating and trading information about a number of different policies and problems. Officials in the Indian government, for example, have examined Brazil's conditional cash transfer programme, Bolsa Familia, in order to prepare their own initiatives for poverty alleviation. For some research questions, of course, comparisons will be less useful, and a purely transnational or global focus more relevant. But if we are interested in explaining variation between and change in the policies of states, including the Brazilian state, comparison is essential. ${ }^{5}$

The second issue that Oliveira Lima grappled with is the limitations of a scholarly area that revolves around one country. In the social sciences, for example, a premium is often placed on generalizable knowledge, and the search for universal models. The major disciplines of social science are devoted to academic specialization and the use of specific methods. At first glance it might seem to practitioners of these disciplines that Brazilian Studies, which do not constitute a discipline (because its practitioners do not use distinctive methods) but rather an area, is useless. Students of economics learn macro and microeconomics, not Brazilian microeconomics or the macroeconomics of Brazil. And yet, as the financial crisis of 2008 reminded us, universalistic models do not always work. The "rational expectations" school in economics, for example, predicted

\footnotetext{
${ }^{5}$ Much remains to be done in this area. A recent evaluation of research done within the Rising Powers portfolio of the UK's Economic and Social Research Council revealed that of its 120 projects funded over the last ten years, roughly 50 (42 percent) were on China, 50 on India, 17 (14 percent) on Russia and only 3 - or barely over 2 percent - on Brazil. Brazil is thus far and away the most understudied "BRIC" country in UK universities. See DFID 2012: 4.
}

Brasiliana - Journal for Brazilian Studies. Vol. 1, n.1 (Sept. 2012). ISSN 2245-4373. 
that over the long term assets would always be accurately priced, because rational economic agents were capable of acquiring sufficient information to measure risk. The kind of real estate bubble that developed in much of the advanced capitalist world was therefore unforeseen. Furthermore, the highly variable degree of resistance to the financial collapse was also unexplained.

This is where Brazilian Studies can be shown to be useful. To continue with the example above, the Brazilian economy recovered from the 2009 recession better than most, in part because its financial sector had been reformed and heavily regulated in previous years. As the economist Werner Baer argued in a speech at the Brazilian Studies Association conference in Brasilia in 2010, knowledge of the historical context and institutional complexity of specific places is vital, even in a discipline with universalistic aspirations such as economics. Deductivism and logic can take one only so far. Macroeconomic models that do not take into account Brazil's institutional makeup and capacity are unlikely to be accurate. Inductivism and empiricism are a necessary complement to the deductivism and abstractness of many social science methods. Brazilian Studies are not an exotic "extra"; they are essential to an understanding of many big, important, global questions. And because many of the challenges facing Brazil are global - for example, how to deal with climate change, how to reduce violence, how to decrease poverty and inequality, how to improve education - Brazilian Studies have much to offer.

It might be thought that a field of study that limits itself to examining the history, economy, politics, society, and culture of one country is inherently limited and less ambitious than other fields that ask big, enduring questions about life and the universe, such as philosophy and astrophysics. But this need not be the case. Brazilian Studies can be as ambitious and as searching as any of the conventional academic disciplines, because it can freely borrow from them in producing answers to its research questions. 
Those answers are unlikely to be satisfying, however, until a more effective dialogue is established between those scholars who publish in Portuguese and those who publish in English (and other languages). A surprising number of classic works written by and for Brazilians over the last century have never been translated into English, for example. (Fortunately, there are new sources of funds for translations of these great books which will be of great benefit to Brazilian Studies scholars.) Similarly, a great many academic studies concerning Brazilian topics in fields such as political science, sociology, anthropology, and comparative literature are never translated into Portuguese. This inhibits the development of cross-cultural understanding in the field.

The third issue that Oliveira Lima confronted, and that is still with us today, is interdisciplinarity. Oliveira Lima was not a professional academic, and was a generalist. Today, professional academics are pressured into becoming more and more specialized. Nevertheless, I agree with Gildo Marçal Brandão (2007) that modern academic specialization is a barrier to asking and answering the really interesting questions about Brazil's economic, political, social, and cultural trajectory. One solution to this dilemma is to bring academics from a number of different disciplines together, and give them the liberty to collaborate, teach, and research together, focusing on selected issues concerning Brazil. This is what many contemporary centres and institutes focusing on Brazil in universities do. An alternative is for an individual to try to emulate Oliveira Lima and become a wide-ranging generalist, capable of reading broadly in the humanities, history, and social science, and interpreting Brazil to a non-specialist audience. This is a more difficult option in the modern university, but an appealing one nonetheless.

\section{A Way Forward in Brazilian Studies?}


Brazilian Studies will probably always remain a broad and eclectic field of study. "Brazil" and "Brazilian" can refer to a country, a state, a national foundational myth, a people, a society, a way of life, a state of mind, a football team, and much else besides. Any attempt to rigidly define the field would probably be unsatisfying, and leave something essential out; that is probably one of the field's attractions. But to remain vital, it should stay on the broad highway connecting the best scholarship in a variety of disciplines; its practitioners must avoid being confined to an exotic cul-de-sac of academic life. To do that, Brazilian Studies scholars should keep in touch with the globalizing world, and incorporate new scholarship from Africa, the Middle East, and Asia. We need new perspectives on old questions from these places.

Second, Brazilian Studies should be cognizant of the theoretical and empirical deconstruction of nationalism, without being defeated by that trend. After all, "imagined communities" retain powerful holds on people, even if they are, ultimately, only imagined. National consciousness and identity may be weakening, but "Brazil" is still a meaningful entity for hundreds of millions of people, and therefore Brazilian Studies also serve a purpose. If nation-states are becoming de-territorialized, to some extent, the Brazilian Studies can follow in the wake of that development, promoting research on Brazilian culture, politics, and the state wherever they manifest themselves around the world.

Finally, we must not be embarrassed to be scholars, people who are excited by ideas and who need time to think. In the present university climate, with its emphasis on fund-raising and "impact", it is all too easy for academics to be pressured into answering only the immediate, practical questions of donors, sponsors, and governments. There is nothing wrong with addressing these concerns, and as Brazil becomes wealthier and more globally influential, the number of actors raising them will increase. But Brazilian Studies will flourish most profusely where researchers have the 
autonomy to ask difficult and awkward questions independent of political projects and commercial interests that are not their own.

\section{References}

Anderson, Benedict. Imagined Communities: Reflections on the Origin and Spread of Nationalism. London: Verso Press, 1987.

Bethell, Leslie. "Brazil and 'Latin America'". In: Journal of Latin American Studies, Volume 42, Number 3, 2919, pp. 457-485.

Boxer, C. R. The Portuguese Seaborne Empire, 1450-1825. Middlesex: Penguin Books, 1973.

Brandão, Gildo Marçal. Linhagens do Pensamento Político Brasileiro. São Paulo: Hucitec Editora, 2007.

Cardim, Carlos Henrique. A Raiz das Coisas: Rui Barbosa, O Brasil no Mundo. São Paulo: Civilização Brasileira, 2008.

Chaui, Marilena. Brasil: Mito Fundador e Sociedade Autoritária. São Paulo: Editora Fundação Perseu Abramo, 1996.

Department for International Development [DFID]. Terms of Reference for a Research Programme/The Brazilian Development Model for Africa: Evidence and Lessons. London: DFID Research, July, 2012.

Gray, John. "Post-Olympics Britain" in The Guardian, 8 September, 2012, Saturday Review, p. 6.

Hobsbawm, Eric. Nations and Nationalism Since 1780. Cambridge: Cambridge University Press, 1991.

Johnson, Ollie. "Afro-Brazilian Politics: White Supremacy, Black Struggle, and Affirmative Action".In: Peter Kingstone and Timothy Power, eds. Democratic Brazil Revisited. Pittsburgh: University of Pittsburgh Press, 2008, pp. 209-230. 
Kamel, Ali. Não Somos Racistas - Uma Reação aos que Querem Nos Transformar numa Nação Bicolor. Rio de Janeiro: Editora Nova Fronteira, 2007.

Oliveira Lima, Manuel de. The Evolution of Brazil Compared with that of Spanish and AngloSaxon America. New York: Russell and Russell, 1996 (first published in 1914).

O'Neill, Jim. The Growth Map: Economic Opportunity in the BRICs and Beyond. London: Portfolio Penguin, 2011.

Maxwell, Kenneth. Naked Tropics: Essays on Empire and Other Rogues. London: Routledge, 2003.

Seigel, Micol. "Beyond Compare: Comparative Method after the Transnational Turn". In: Radical History Review, Issue 91, Winter, 2005, pp. 62-90.

Steger, Manfred B. Globalization: A Very Short Introduction. Oxford: Oxford University Press, 2009.

Tilly, Charles. Coercion, Capital, and European States AD 990-1992. Oxford: Blackwell, 1990. 